\title{
Rationalizing the Investment Decision in Computerized Accounting Information Systems - An Applied Study on Saudi Arabian Companies
}

\author{
Sherif S. Elbarrad \\ Correspondence: Sherif S. Elbarrad, Faculty at Grant Macewan University, 10700104 Ave, Edmonton, AB T5J \\ 4S2, Alberta, Canada. (Associate Professor of Accounting \& Auditing at Faculty of Commerce, Ain-Shams \\ University, Cairo, Egypt). E-mail: elbarrads@macewan.ca
}

Received: May 20, 2012

doi:10.5539/ijef.v4n8p42

\author{
Accepted: June 4, 2012 \\ Online Published: July 2, 2012 \\ URL: http://dx.doi.org/10.5539/ijef.v4n8p42
}

\begin{abstract}
This paper aims to help companies to rationalize their investments in Computerized Accounting Information Systems (CAIS hereafter) through focusing on the experience of companies that have changed their systems. The paper opted for a survey research approach using a questionnaire which has been tested for its content validity. The questionnaire has been designed to capture the experience of companies that have changed their CAIS. The questionnaires were distributed among both accountants and managers of Saudi Arabian companies of different sizes and fields that have experienced problems in their CAIS. The paper provides an insight of the reasons behind the decision to change CAIS based on the practical experience of companies in Saudi Arabia. It shows that there has been a significant change in the priorities of choosing a CAIS due to experience. It is noted also that there are some features which are available in CAIS which are not widely required by system users, and hence, it would be unwise to pay for their costs. Finally, it is noted that there is no significant difference between the managers and the accountants' requirement regarding CAIS.
\end{abstract}

Keywords: computerized accounting information system, management information system, Saudi Arabia, investment decisions

\section{Introduction}

The advancements in Information Technology resulted in the reliance of companies on performing their business in an electronic form. A lot of companies in the Middle East started to use Computerized Accounting Information Systems ("CAIS" hereafter). A number of research studies showed that business generally were disappointed with their new purchases of CAIS. They did not get the benefits they expected, and the projects took substantially longer and cost more than anticipated (Tate, 1999). Ivancevich (S. Ivancevich, H. Ivancevich, \& Elikai, 2010) stated that selecting the right accounting software is critical to any business. A wrong choice could mean incompatibility problems, functional limitations, and frustration, as well as unhappy workers and customers. The right choice means that a business can focus on the products or services that are relevant to its core business model rather than losing effort, time and money trying to overcome CAIS problems.

Building or rebuilding of CAIS is an expensive task, as it requires a lot of time, effort and money in each of the stages of building such a system whether in the stage of planning, analyzing, designing or implementing the system. Accordingly, it is assumed that such cost would have a positive effect on the organization performance in the form of increasing its profits on the long term. To achieve this, such resources have to be managed and employed in a good manner. This depends on a full understanding of how to utilize such systems to support the needs of the decision maker (Alkary, 2005).

It is noticed also in some Middle Eastern countries that companies (specially small and mid-size) face changing of CAIS several times due to the inappropriateness of it to their requirements.

The success of CAIS usage depends not only on the amount of the investments, but the right choice of hardware, software, database and personal qualifications. All these components are closely connected among themselves and reflect common, useful results, which have to be evaluated from economic, technical and social aspects (Asta Raupeliene\& Linas Stabingis, 2003). 
The importance of the output of accounting information systems is emphasized in several researches. $\mathrm{Xu}(\mathrm{Xu}$, 2009) stated that the quality of information is one of the competitive advantages for an organization. In an accounting information system, the quality of information provided is imperative to the success of the systems.

Meall (Meall, 2009) supported such opinion by stating that the information produced by CAIS is regarded as one of the basic resources of the organizations. It is the base of financial decision making whether it is related to operating, investing or financing decisions. Such decisions contribute to increase the level of organizational performance and create a strategic advantage to it, which reflects on its market value and hence increase investors' wealth. Also, Redman supported this (Redman, 1992) by stating that inaccurate or incomplete data may adversely affect the competitive success of an organization. Nord also supported this (Nord, Jeretta Horn Nord, \& Xu, 2005) by stating that poor quality information can have a significant social and business impact.

However, the reliance on such CAIS has its accompanying risks. The system can fail due to several reasons such as the inability of users to cope with it, or it is technically inadequate to fulfill the company's requirements, or the riskiness of using it on the company's resources....etc. There are also operational risks as using such systems could lead to losing the company's assets whether by losing data or failure of the system to record all accounting information in a correct manner, or it could not be secured correctly which enables hackers or unauthorized users to access the system and change data whether intentionally or unintentionally.

Choosing an accounting system for large enterprise has never been easy, but then again it has never been more difficult than it is right now (Meall, 2009). Correctly choosing CAIS can have a positive influence on not only data processing, but also on the efficiency of an enterprise's activity (Asta Raupeliene\& Linas Stabingis, 2003). All these factors show the importance of concentrating on the process of selecting the most suitable CAIS before implementing it.

This research shares the definition of the effectiveness of CAIS with another research (Nicolaou I., 2000) where it is defined in terms of the perceptions of decision makers that the output information available to them through transaction processing, management reporting, and budgeting systems meets their requirements for organizational coordination and control. Accordingly, to determine the effectiveness of CAIS, a comparison between the needs of users and company management are matched with the CAIS capabilities and features to find out the extent to which such CAIS meets those requirements.

\section{Literature Review}

The researches, which have been implemented in such a field, could be classified as follows:

\subsection{Research Related to the Risk of Implementing CAIS}

Yau and Auyeun (Yau \& Auyeung, June 29 - July 2, 1995) studied the risks of implementing a CAIS, and they found that they were related to some problems such as; users are opposing the adoption of new techniques; the availability of "off-the-shelf" software (as a cheaper alternative to the tailored made software) implied that users have to try to fit their requirement to the software's capabilities; very few CAIS actually perform sophisticated management and cost accounting systems;

S.Ivancevich, (Ivancevich et al., 2010) studied the factors that influence the CAIS selection and those that lead to satisfaction. They surveyed a large number of professionals, and questioned several suggested factors that could affect the software's selection and satisfaction. The distributed questionnaire also addressed other issues such as what are the most important areas for improving the software and the reasons behind not changing the software. The results revealed that the functionality of the software was rated as most important to users when selecting the software. Also, security of data and real-time processing topped the list in importance. While report-writing and flexibility topped the areas of improvement. The "cost" appeared to be the most important obstacle for changing the software, and then the hassle associated with such a change comes next. It is also noted that there has been some similarities and differences between large and small company users. The study concluded that there is a need to develop a standard set of measures for management to ascertain the impact of information technology investment on the accounting system.

The conclusion of the previous study goes in coherent with the goals of this research, where it identifies the companies' requirements of CAIS and determining their priorities when choosing such systems in order to rationalize their investments in such a field. This goal implies that the CAIS should be fitting the requirements of the accountant's and the decision makers' needs. It is to be noted that the requirements of the decision makers could differ according to the culture and the environment in which the CAIS is implemented. This research will explore the CAIS selecting criteria in Saudi Arabia. Additionally, it will attempt to find the reasons of 
abandoning CAIS to another new one and it will test the fitness of the current implemented CAIS to the users' needs.

\subsection{Research Related to Developing Models of Evaluating CAIS}

There are different researches that strived to develop a model of evaluating CAIS. Raupeliene and Stabingis, (Asta Raupeliene \& Linas Stabingis, 2003) studied the models of evaluating CAIS and analysed the theoretical aspects of the enterprise's AIS effectiveness and formulated the following conclusions:

- The effectiveness of CAIS can be considered successful if it ensures user's needs.

- Most of the models which are provided in academic publications allow the evaluation of CAIS effectiveness only from technical-economic or in social-economic aspect.

- There isn't an integrated and for practical usage adjusted CAIS effectiveness evaluation model which allow CAIS effectiveness evaluation from economic, technical and social aspects contemporaneously.

The study suggested a theoretical mathematical model to measure the effectiveness of the CAIS; however, it didn't apply such a model in practice and it didn't show how companies could use such a model to be a useful tool in the process of choosing a new CAIS to be implemented. This adds to the importance of this research as it focuses on the features that is most important for users and explores the alignment of the users' needs with the CAIS capabilities, hence rationalizing the investment in such a field. Additionally, it could be regarded as a step towards designing a model to aid in choosing the CAIS for small and medium sized companies.

Ismail and king (Ismail \& King, 2005) studied the relation between firm performance and CAIS alignment. Where they explored the fit between AIS requirements and AIS capacity and whether this fit is linked to performance in Small and Medium size Enterprises (SMEs). It measured AIS requirements in terms of importance to the business attached to 19 accounting information characteristics. AIS capacity was measured in terms of the Information System support available for each of the 19 accounting information characteristics. The results suggest that the firms' AIS processing capacities were in many cases insufficient to match their AIS requirements, which implies that the managers of SMEs were not being as effective as they could be in utilizing IT. Further, the results of the moderation perspective of measuring of fit indicated varying degrees of alignment of the nineteen information characteristics. However, using cluster analysis, three significantly different AIS alignment groups were later identified which could be clearly labeled as "aligned", "moderate", and "non-aligned". Finally, the three AIS alignment groups were tested against performance. The results show a positive association between AIS alignment and firm performance. Such results are of importance to the current research due to the fact that there is a positive association between CAIS alignment and firm's performance would lead to the conclusion that aligning CAIS would rationalize the investment in CAIS which is the goal of this research. Accordingly, this research will be exploring such alignment in the Saudi market and focusing on the important features which are required by the users of the CAIS.

\section{Data Collection}

This research aims to provide the experience of companies that implemented CAIS more than one time to be used to rationalize the investment in such field. It should answer questions of whether the priorities have changed from the first to the second time of implementation; what are the mostly required specifications of CAIS by companies and if the new implemented system fulfills such needs; whether the new CAIS comprises solutions to the previous problems that were the main reason of abandoning the previous CAIS; and finally whether the features of the CAIS differ from an accountant to a manager perspective. Based on such discussion, this research tests six hypothesis to answer those questions. The data are gathered through a questionnaire.

\subsection{Designing of the Questionnaire}

The questionnaire is designed to collect the information required to test the research hypothesis and to achieve the research objectives. (Appendix I).

\subsubsection{Assessing Questionnaire Validity}

The researcher has used the content validity method to assess the validity of the research questionnaire. The researcher has selected 15 experts in the area of accounting including academician (mainly University faculty members) and practitioners (accountants and managers working in professional firms) and distributed the questionnaire to them with a cover letter explaining the objectives and hypothesis of the study and asking them to indicate whether the questions in the attached questionnaire collect the data required to test the hypothesis and achieve the study objectives. 
Most of them agreed that the questionnaire collects the required data and some of them had some concerns related to some questions as well as adding additional questions to cover the research objectives and hypothesis. The questionnaire is updated accordingly.

\subsubsection{Assessing Questionnaire Reliability}

The researcher has used the Test-retest method to assure that the questions are clear and specific and homogenous. With regard to test - retest method the researcher selected a small group of the research population (accountants \& managers) and distributed the questionnaire to them and after 5 days he distributed the questionnaire a second time and the data was analyzed, and a correlation coefficient of the results of the first and second test is conducted, and it has been found that it is significant.

\subsection{Sample of the Study}

A number of 300 questionnaires have been distributed among accountants and senior decision making managers working in firms operating in Saudi Arabia that have changed their CAIS at least once. The questionnaire has been distributed randomly. The returned questionnaires amounted to 136 questionnaires (45.3\%). Questionnaires were analyzed, and it was found that 15 questionnaires were invalid as either they were not complete or not answered in a valid way (such as repeating numbers in prioritizing the factors that affect the selection of CAIS). etc. Hence, there are 121 valid questionnaires collected representing $40.3 \%$ of the valid questionnaires. The distribution of the sample according to companies' field of business were as follows: Industrial $30 \%$; Services $57 \%$ and Trading $13 \%$.

To determine the size of the companies which comprises the sample of the study, two measures are considered; number of employee and capital size. Around $78 \%$ of the sample's companies employ more than 100 employees, while the mid-size companies (employing from 50-100 employees) represented $9 \%$, and around $13 \%$ employed less than 50 employees.

From a capital perspective, the big companies (more than SR 50 million of capital) represent more than two thirds of the sample, while mid-size companies (SR 10- 50 million of capital) represented $9 \%$, while companies with less than SR 10 million represented 21\%. This measure of company size also supports the previous number of employees' measure, where both showed that large companies have greater weight in the sample size which is appropriate with the objective of the research.

\section{Testing the Research Hypothesis and Findings}

The researcher used the statistical program SPSS to perform the statistical analysis.

4.1 Testing the First Hypothesis: H1- The Priorities of CAIS Choosing Criteria Did Not Differ Significantly from the First to the Second Time of Implementation

Table 1. Determining the priorities of selecting CAIS

\begin{tabular}{llllllllllll}
\hline Order & 1 & 2 & 3 & 4 & 5 & 6 & 7 & 8 & 9 & 10 \\
\hline Fist time & FO-1 & FO-5 & FO-6 & FO-4 & FO-3 & FO-9 & FO-2 & FO-7 & FO-8 & FO-10 \\
Frequency & 40 & 30 & 29 & 15 & 6 & 1 & 0 & 0 & 0 & 0 \\
Second time & FC-5 & FC-6 & FC-9 & FC-3 & FC-1 & FC-4 & FC-10 & FC-2 & FC-8 & FC-7 \\
Frequency & 44 & 33 & 11 & 10 & 9 & 7 & 4 & 2 & 1 & 0 \\
\hline
\end{tabular}

F1 Cost of acquiring the CAIS software

F2 User friendliness

F3 Easiness of system implementation

F4 The level of support provided by the CAIS developer

F5 CAIS capabilities and features

F6 Ability of CAIS to grow and be developed to meet future company growth

F7 Availability of full detailed manuals for the CAIS

F8 The developer of the software has a long list of clients

F9 Experience and reputation of the CAIS developer

F10 Cost of the needed Hardware (or compatibility of the present hardware) to run the CAIS

$\mathrm{FO}=$ Factors of Old CAIS $\quad \mathrm{FC}=$ Factors of Current CAIS 
It is clear that the priorities of the selection criteria of the respondents have changed when implemented the CAIS from the first to the second time of implementation. To stand on the significance of such difference a ranked T-Test is performed for the relative frequencies of question 4 (variables FC) and 5 (variables FO) of the questionnaire and the following results could be summarized.

Table 2.

\begin{tabular}{|c|c|c|c|c|c|}
\hline Factor & Mean & Std. Deviation & Rank & T Test & Sig. \\
\hline FC-1 & 4.74 & 2.38 & 4 & \multirow{2}{*}{3.732} & \multirow{2}{*}{$0.000^{(*)}$} \\
\hline FO-1 & 3.53 & 2.75 & 1 & & \\
\hline FC-2 & 5.40 & 2.59 & 6 & \multirow{2}{*}{0.324} & \multirow{2}{*}{0.746} \\
\hline FO-2 & 5.33 & 2.55 & 5 & & \\
\hline FC-3 & 5.36 & 2.49 & 5 & \multirow{2}{*}{-0.631} & \multirow{2}{*}{0.529} \\
\hline FO-3 & 5.50 & 2.11 & 6 & & \\
\hline $\mathrm{FC}-4$ & 4.45 & 2.17 & 3 & \multirow{2}{*}{-0.036} & \multirow{2}{*}{0.971} \\
\hline FO-4 & 4.45 & 2.61 & 4 & & \\
\hline FC-5 & 3.24 & 2.59 & 2 & \multirow{2}{*}{-2.156} & \multirow{2}{*}{$0.033^{(*)}$} \\
\hline FO-5 & 3.82 & 2.77 & 2 & & \\
\hline FC-6 & 3.16 & 2.37 & 1 & \multirow{2}{*}{-3.721} & \multirow{2}{*}{$0.000^{(*)}$} \\
\hline FO-6 & 4.45 & 3.17 & 3 & & \\
\hline FC-7 & 6.99 & 2.24 & 8 & \multirow{2}{*}{-3.891} & \multirow{2}{*}{$0.000^{(*)}$} \\
\hline FO-7 & 7.85 & 1.97 & 10 & & \\
\hline FC-8 & 7.34 & 2.46 & 9 & \multirow{2}{*}{-1.867} & \multirow{2}{*}{0.064} \\
\hline FO-8 & 7.85 & 2.11 & 9 & & \\
\hline FC-9 & 6.69 & 2.46 & 7 & \multirow{2}{*}{3.260} & \multirow{2}{*}{$0.001^{(*)}$} \\
\hline FO-9 & 6.04 & 1.83 & 7 & & \\
\hline FC-10 & 7.50 & 2.72 & 10 & \multirow{2}{*}{5.037} & \multirow{2}{*}{$0.000^{(*)}$} \\
\hline FO-10 & 6.14 & 2.71 & 8 & & \\
\hline
\end{tabular}

Based on the previous table it could be concluded that there is a significant difference in priorities between the $1^{\text {st }}$ and $2^{\text {nd }}$ time of implementing the CAIS for the following factors; cost of acquiring the CAIS software (FC- 1 \& FO-1); CAIS capabilities and features (FC-5 \& FO-5); Ability of CAIS to grow and be developed to meet future company growth (FC-6 \& FO-6);Availability of full-detailed manuals for the CAIS (FC-7 \& FO-7); Experience and reputation of the CAIS developer (FC-9 \& FO-9); Cost of the needed hardware (or compatibility of the present hardware) to run the CAIS (FC-10 \& FO-10);

While there is no significant difference in priorities between the $1^{\text {st }}$ and $2^{\text {nd }}$ time of implementing the CAIS for the following factors; user friendliness (FC-2 \& FO-2); Easiness of system implementation (FC-3 \& FO-3), the level of support provided by the CAIS developer (FC-4 \& FO-4); and the developer of the software has a long list of clients (FC-8 \& FO-8).

Based on the previous discussion it is clear that there were only four of the factors which didn't change significantly from the first to the second time of implementation, while the other six factors have changed significantly. Accordingly, the null hypothesis of $\mathrm{H} 1$ could be rejected, and the alternative hypothesis is accepted which states:

"The priorities of CAIS choosing criteria changed significantly when implementing such system from the first to the second time."

\subsection{Testing the Second \& Third Hypothesis}

The two hypotheses are formulated as follows: 
H2: The CAIS implemented in the company fulfill the company's mostly needed requirements.

H3: CAIS features which are regarded as important by companies are present in the CAIS system implemented.

\subsubsection{Determining the Required Features by Companies and Their Availability in CAIS}

Based on analysing the questionnaire, a comparison is done between 20 features required by the company's accountants and managers and those features already available in the system. The following results are found:

Table 3.

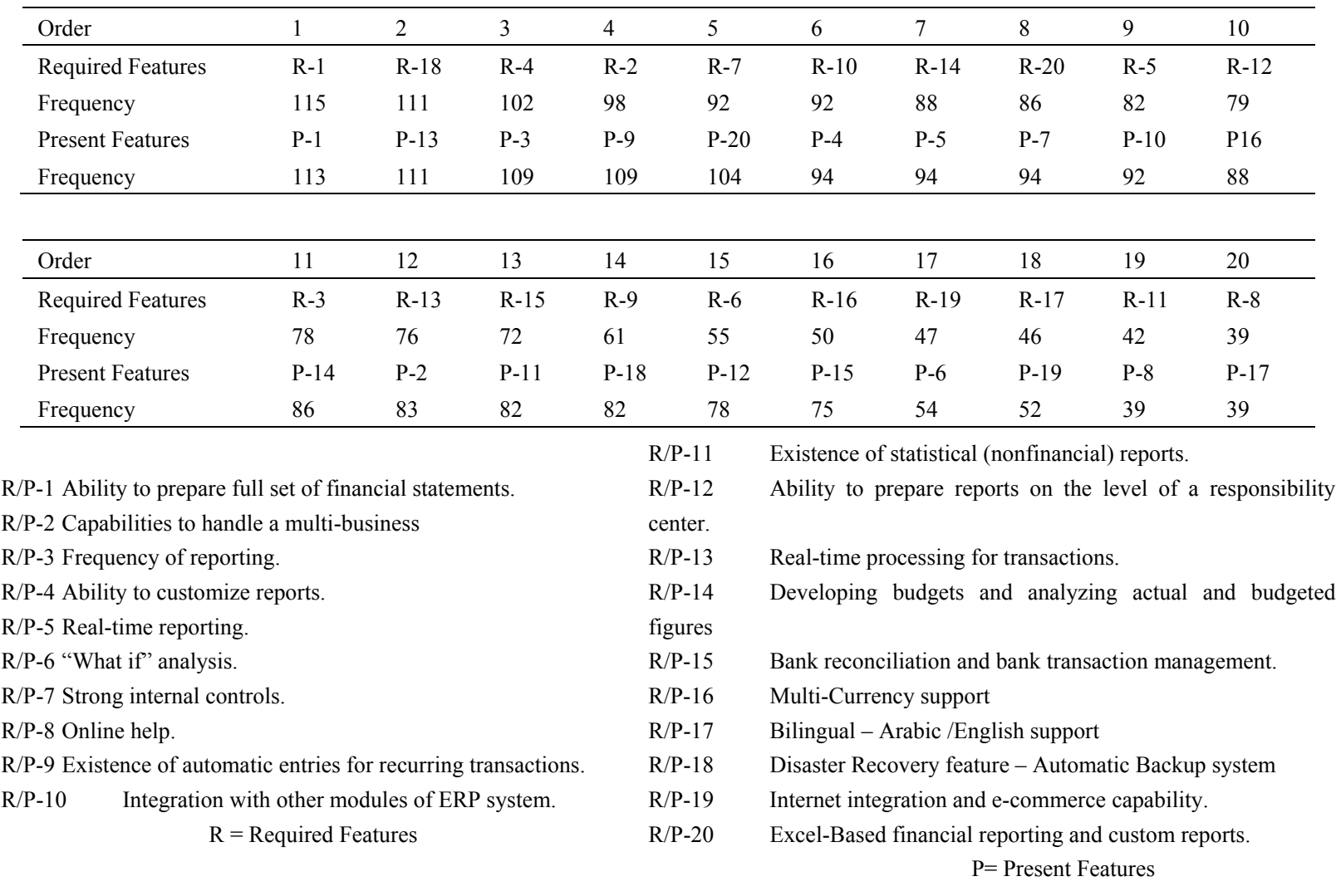

Based on the previous table it could be concluded that the features required by the companies are not necessarily available by the same importance. The only features which is common in importance between what is required and what is available, is the preparation of a full set of financial statements (R-1) and (P-1) respectively. However, all the other features differed in importance (based on the frequency of the responses) between what is required and what is available.

\subsubsection{Determining the Alignment of The CAIS Features to The Companies Requirements}

In order to observe the available CAIS features alignment with those features required by the companies, a cross tabulation is prepared for each of the features in Question 6 (asking about the companies' preferred features) with the adjacent features in Question 7 (asking about the available features in the present CAIS).

The availability of the features is classified into three groups as follows:

- Highly available: Are those features which are reported by more than $75 \%$ of the respondents as "Available".

- Moderate Availability: Are those features which are reported by more than $50 \%$ and less than $75 \%$ of the respondents as "Available".

- Low Availability: Are those features which are reported by less than $50 \%$ of the respondents as "Available".

Respondents are asked to determine whether each feature is either "insignificant", "Neutral" or "important". The following table summarizes such results. 
Table 4.

\begin{tabular}{|c|c|c|c|}
\hline \multirow{2}{*}{$\begin{array}{l}\text { Importa } \\
\text { nce }\end{array}$} & \multicolumn{3}{|c|}{ Availability } \\
\hline & Low & Moderate & High \\
\hline High & & $\begin{array}{l}\text { - Capabilities to handle multi-business; } \\
\text { - Disaster Recovery feature (Automatic } \\
\text { Backup system). }\end{array}$ & $\begin{array}{l}\text { - Ability to prepare full set of } \\
\text { financial statements. } \\
\text { - Ability to customize reports. } \\
\text { - Integration with other modules of } \\
\text { ERP system. }\end{array}$ \\
\hline Moderate & & $\begin{array}{l}\text { - Ability to prepare reports on the level of } \\
\text { a responsibility center. } \\
\text { - Developing budgets and analyzing actual } \\
\text { and budgeted figures. } \\
\text { - Bank reconciliation and bank transaction } \\
\text { management. }\end{array}$ & $\begin{array}{l}\text { - Frequency of reporting } \\
\text { - Real-time reporting. } \\
\text { - Strong internal controls. } \\
\text { - Real-time processing for } \\
\text { transactions. } \\
\text { - Excel-Based financial reporting and } \\
\text { custom reports. }\end{array}$ \\
\hline Low & $\begin{array}{l}\text { - "What if" analysis } \\
\text { - Online help. } \\
\text { - Bilingual - Arabic /English } \\
\text { support. } \\
\text { - Internet integration and } \\
\text { e-commerce capability. }\end{array}$ & $\begin{array}{l}\text { - Existence of statistical (nonfinancial) } \\
\text { reports. } \\
\text { - Multi-Currency support. }\end{array}$ & $\begin{array}{l}\text { Existence of automatic entries for } \\
\text { recurring transactions }\end{array}$ \\
\hline
\end{tabular}

Based on the previous table the following could be deduced:

- There are 9 features representing $45 \%$ of the features are "Highly available", while, 3 features of them are of high importance, and 5 are of moderate importance, and 1 is of low importance.

- There are 7 features representing 35\% are "Moderately available", while 2 features of them are of high importance, and 3 are of moderate importance, and 2 are of low importance.

- There are 4 features representing 20\% are of "Low availability", and all of them are of low importance.

- On the other hand, there are 5 features which are regarded as important by the accountants, 3 features (representing 60\%) are highly available, while 2 features (representing 40\%) are moderately available. Hence, we can accept $\mathrm{H} 2$ and $\mathrm{H} 3$ of the research indicating that the CAIS implemented in the company fulfil the companies mostly required specification, and the CAIS features which are regarded as important by accountants, are present in the CAIS system implemented by their companies.

4.3 Testing The Fourth Hypothesis: H4 -The Features, Which Were One of The Reasons of Abandoning the Previous CAIS, Are Present in The Currently Adopted CAIS

4.3.1 Determining the Real Factors of Abandoning CAIS

In order to determine the factors which lead to abandoning a CAIS system, question 7 of the questionnaire is analysed and the following could be concluded. 
Table 5.

\begin{tabular}{lllllllllll}
\hline Order & 1 & 2 & 3 & 4 & 5 & 6 & 7 & 8 & 9 & 10 \\
\hline $\begin{array}{l}\text { Feature that lead to the } \\
\text { departure }\end{array}$ & A-10 & A-14 & A-2 & A-18 & A-20 & A-7 & A-1 & A-12 & A-3 & A-4 \\
\hline Frequency & 69 & 64 & 63 & 60 & 58 & 53 & 52 & 52 & 46 & 46 \\
\hline & 11 & 12 & 13 & 14 & 15 & 16 & 17 & 18 & 19 & 20 \\
\hline Order & A-9 & A-13 & A-5 & A-17 & A-6 & A16 & A-15 & A-11 & A-19 & A-8 \\
\hline $\begin{array}{l}\text { Feature that lead to the } \\
\text { departure }\end{array}$ & 42 & 35 & 31 & 28 & 23 & 23 & 22 & 19 & 18 & 13 \\
\hline \begin{tabular}{l} 
Frequency \\
\hline
\end{tabular}
\end{tabular}

$\mathrm{A}=$ Features that lead to abandoning a CAIS system.

By applying Chi square Test to the answers of the respondents to question 7 of the questionnaire and by comparing the availability of the features which were a cause of abandoning the previous CAIS, the following results are found: (review table " 3 " for codes)

Table 6.

\begin{tabular}{|c|c|c|c|c|c|c|c|c|c|}
\hline \multirow[t]{2}{*}{ Feature \# } & \multirow{2}{*}{$\begin{array}{l}\text { Available in the } \\
\text { current system }\end{array}$} & \multicolumn{2}{|c|}{$\begin{array}{c}\text { Not Cause of } \\
\text { change }\end{array}$} & \multicolumn{2}{|c|}{ Cause of change } & \multicolumn{2}{|c|}{ Total } & \multirow[b]{2}{*}{ Chi Square } & \multirow[t]{2}{*}{ Sig. } \\
\hline & & \# & $\%$ & \# & $\%$ & \# & $\%$ & & \\
\hline \multirow{3}{*}{1} & Not Available & 8 & 11.6 & 0 & 0.0 & 8 & 6.6 & \multirow{3}{*}{6.46} & \multirow{3}{*}{0.011} \\
\hline & Available & 61 & 88.4 & 52 & 100 & 113 & 93.4 & & \\
\hline & Total & 69 & 100 & 52 & 100 & 121 & 100 & & \\
\hline \multirow{3}{*}{2} & Not Available & 38 & 65.5 & 0 & 0.0 & 38 & 31.4 & \multirow{3}{*}{60.17} & \multirow{3}{*}{0.000} \\
\hline & Available & 20 & 34.5 & 63 & 100 & 83 & 68.6 & & \\
\hline & Total & 58 & 100 & 63 & 100 & 121 & 100 & & \\
\hline \multirow{3}{*}{3} & Not Available & 10 & 13.3 & 2 & 4.3 & 12 & 9.9 & \multirow{3}{*}{2.58} & \multirow{3}{*}{0.108} \\
\hline & Available & 65 & 86.7 & 44 & 95.7 & 109 & 90.1 & & \\
\hline & Total & 75 & 100 & 46 & 100 & 121 & 100 & & \\
\hline \multirow{3}{*}{4} & Not Available & 25 & 33.3 & 2 & 4.3 & 27 & 22.3 & \multirow{3}{*}{13.82} & \multirow{3}{*}{0.001} \\
\hline & Available & 50 & 66.7 & 44 & 97.8 & 94 & 78.3 & & \\
\hline & Total & 75 & 100 & 46 & 100 & 121 & 100 & & \\
\hline \multirow{3}{*}{5} & Not Available & 26 & 28.9 & 1 & 3.2 & 27 & 22.3 & \multirow{3}{*}{8.76} & \multirow{3}{*}{0.003} \\
\hline & Available & 64 & 71.1 & 30 & 96.8 & 94 & 77.7 & & \\
\hline & Total & 90 & 100 & 31 & 100 & 121 & 100 & & \\
\hline \multirow{3}{*}{6} & Not Available & 66 & 67.3 & 1 & 4.3 & 67 & 55.4 & \multirow{3}{*}{29.92} & \multirow{3}{*}{0.000} \\
\hline & Available & 32 & 32.7 & 22 & 95.7 & 54 & 44.6 & & \\
\hline & Total & 98 & 100 & 23 & 100 & 121 & 100 & & \\
\hline \multirow{3}{*}{7} & Not Available & 27 & 39.7 & 0 & 0.0 & 27 & 22.3 & \multirow{3}{*}{27.09} & \multirow{3}{*}{0.000} \\
\hline & Available & 41 & 60.3 & 53 & 100 & 94 & 77.7 & & \\
\hline & Total & 68 & 100 & 53 & 100 & 121 & 100 & & \\
\hline & Not Available & 81 & 75.0 & 1 & 7.7 & 82 & 67.8 & & \\
\hline 8 & Available & 27 & 25.0 & 12 & 92.3 & 39 & 32.2 & 24.07 & 0.000 \\
\hline & Total & 108 & 100 & 13 & 100 & 121 & 100 & & \\
\hline & Not Available & 11 & 13.9 & 1 & 2.4 & 12 & 9.9 & & \\
\hline 9 & Available & 68 & 86.1 & 41 & 97.6 & 109 & 90.1 & 4.09 & 0.043 \\
\hline & Total & 79 & 100 & 42 & 100 & 121 & 100 & & \\
\hline & Not Available & 28 & 53.8 & 1 & 1.4 & 29 & 24.0 & & \\
\hline 10 & Available & 24 & 46.2 & 68 & 98.6 & 92 & 76.0 & 44.68 & 0.000 \\
\hline & Total & 52 & 100 & 69 & 100 & 121 & 100 & & \\
\hline
\end{tabular}




\begin{tabular}{|c|c|c|c|c|c|c|c|c|c|}
\hline \multirow{3}{*}{11} & Not Available & 39 & 38.2 & 0 & 0.0 & 39 & 32.2 & \multirow{3}{*}{10.72} & \multirow{3}{*}{0.000} \\
\hline & Available & 63 & 61.8 & 19 & 100 & 82 & 67.8 & & \\
\hline & Total & 102 & 100 & 19 & 100 & 121 & 100 & & \\
\hline \multirow{3}{*}{12} & Not Available & 43 & 62.3 & 0 & 0.0 & 43 & 35.5 & \multirow{3}{*}{50.27} & \multirow{3}{*}{0.000} \\
\hline & Available & 26 & 37.7 & 52 & 100 & 78 & 64.5 & & \\
\hline & Total & 69 & 100 & 52 & 100 & 121 & 100 & & \\
\hline \multirow{3}{*}{13} & Not Available & 10 & 11.6 & 0 & 0.0 & 10 & 8.3 & \multirow{3}{*}{4.44} & \multirow{3}{*}{0.035} \\
\hline & Available & 76 & 88.4 & 35 & 100 & 111 & 91.7 & & \\
\hline & Total & 86 & 100 & 35 & 100 & 121 & 100 & & \\
\hline \multirow{3}{*}{14} & Not Available & 34 & 59.6 & 1 & 1.6 & 35 & 28.9 & \multirow{3}{*}{40.48} & \multirow{3}{*}{0.000} \\
\hline & Available & 23 & 40.4 & 63 & 98.4 & 86 & 71.1 & & \\
\hline & Total & 57 & 100 & 64 & 100 & 121 & 100 & & \\
\hline \multirow{3}{*}{15} & Not Available & 45 & 45.4 & 1 & 4.5 & 46 & 35.9 & \multirow{3}{*}{12.78} & \multirow{3}{*}{0.001} \\
\hline & Available & 54 & 54.6 & 21 & 95.5 & 75 & 64.1 & & \\
\hline & Total & 99 & 100 & 22 & 100 & 121 & 100 & & \\
\hline \multirow{3}{*}{16} & Not Available & 33 & 33.7 & 0 & 0.0 & 33 & 27.3 & \multirow{3}{*}{16.65} & \multirow{3}{*}{0.001} \\
\hline & Available & 65 & 66.3 & 23 & 100 & 88 & 72.7 & & \\
\hline & Total & 98 & 100 & 23 & 100 & 121 & 100 & & \\
\hline \multirow{3}{*}{17} & Not Available & 82 & 88.2 & 0 & 0.0 & 82 & 67.8 & \multirow{3}{*}{76.60} & \multirow{3}{*}{0.000} \\
\hline & Available & 11 & 11.8 & 28 & 100 & 39 & 32.2 & & \\
\hline & Total & 93 & 100 & 28 & 100 & 121 & 100 & & \\
\hline \multirow{3}{*}{18} & Not Available & 39 & 63.9 & 0 & 0.0 & 39 & 32.2 & \multirow{3}{*}{56.61} & \multirow{3}{*}{0.000} \\
\hline & Available & 22 & 36.1 & 60 & 100 & 82 & 67.8 & & \\
\hline & Total & 61 & 100 & 60 & 100 & 121 & 100 & & \\
\hline \multirow{3}{*}{19} & Not Available & 69 & 67.0 & 0 & 0.0 & 69 & 57.0 & \multirow{3}{*}{28.06} & \multirow{3}{*}{0.000} \\
\hline & Available & 34 & 33.0 & 18 & 100 & 52 & 43.0 & & \\
\hline & Total & 103 & 100 & 18 & 100 & 121 & 100 & & \\
\hline \multirow{3}{*}{20} & Not Available & 17 & 27.0 & 0 & 0.0 & 17 & 14.0 & \multirow{3}{*}{18.21} & \\
\hline & Available & 46 & 73.0 & 58 & 100 & 104 & 86.0 & & 0.000 \\
\hline & Total & 63 & 100 & 58 & 100 & 121 & 100 & & \\
\hline
\end{tabular}

Based on the previous table, it could be concluded that Chi square test is significant for all of the features except for the frequency of reporting which appeared to be insignificant. Accordingly, it could be concluded that there is a relationship between the cause of change and the availability of the feature in the newly adopted CAIS, which is logical as those who are selecting the new CAIS would be looking for the features which were one of the reasons of abandoning the old CAIS. Accordingly, the fourth hypothesis $\mathrm{H} 4$ of this research could be accepted, indicating that the features which were one of the reasons of abandoning the previous CAIS, are present in the currently adopted CAIS.

\subsection{Testing the Fifth Hypothesis: H5 -The Features Which Were One of the Reasons of Abandoning the Previous CAIS Are Those Features Which Are Regarded by the Respondents as "Important"}

To test such hypothesis an analysis to the reasons of abandoning the old CAIS (in question 7) are compared by the importance of the feature (in question 6). By applying Chi square Test, the following results are obtained: (review table " 3 " for codes)

Table 7.

\begin{tabular}{lllllllllll}
\hline & Cause & \multicolumn{2}{c}{ Not Cause } & \multicolumn{2}{c}{ Cause } & \multicolumn{2}{c}{ Total } & & Chi Square & Sig. \\
\cline { 2 - 8 } Item \# & Importance & $\#$ & $\%$ & $\#$ & $\%$ & $\#$ & $\%$ & & \multirow{2}{*}{0.029} \\
\hline \multirow{2}{*}{1} & Natural & 6 & 8.7 & 0 & 0.0 & 6 & 5.0 & & \\
& Important & 63 & 91.3 & 52 & 100 & 115 & 95.0 & 4.76 & & 0.000 \\
\hline & Total & 69 & 100 & 52 & 100 & 121 & 100 & & 30.85 & \\
\hline
\end{tabular}




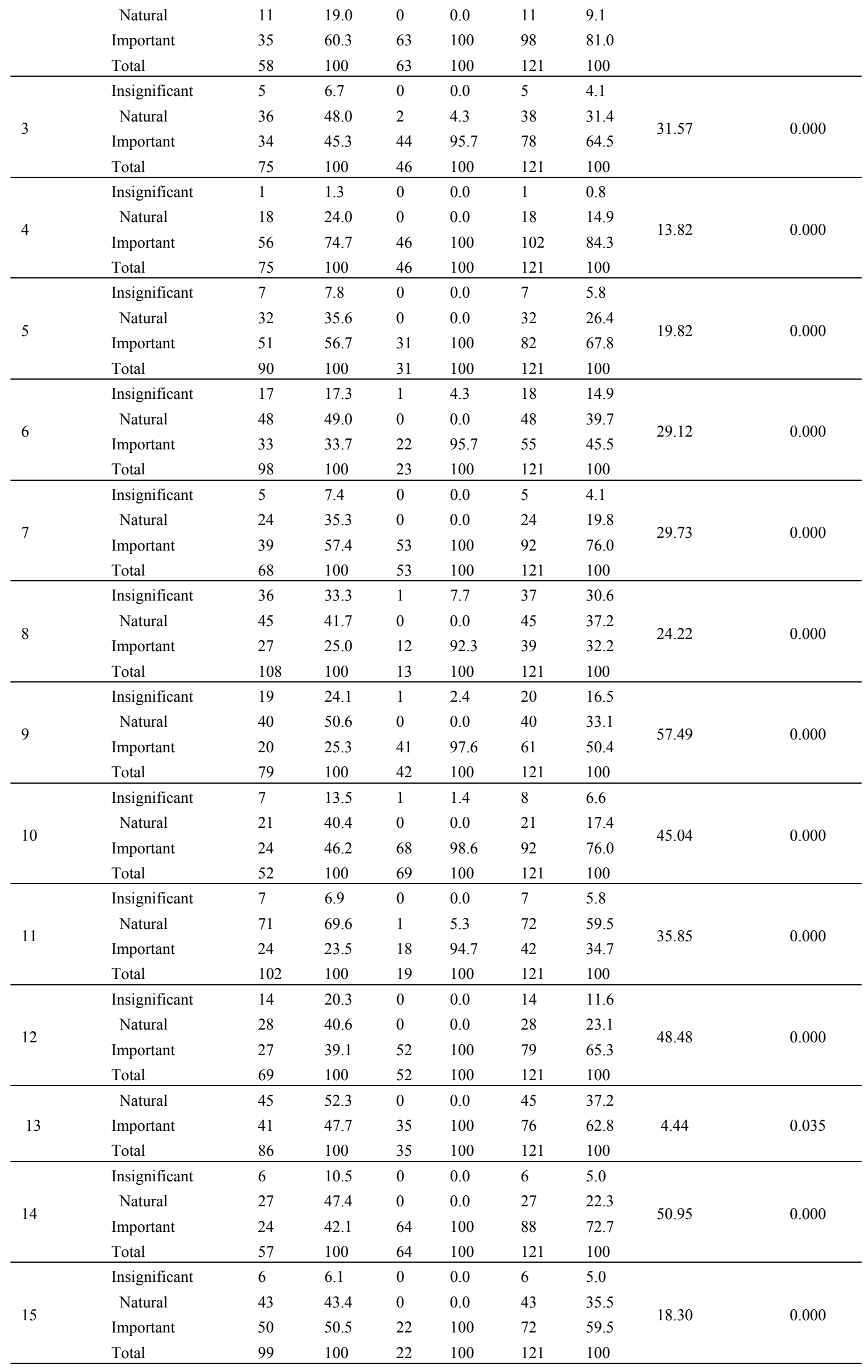




\begin{tabular}{|c|c|c|c|c|c|c|c|c|c|}
\hline \multirow{4}{*}{16} & Insignificant & 24 & 24.5 & 0 & 0.0 & 24 & 19.8 & \multirow{4}{*}{40.33} & \multirow{4}{*}{0.000} \\
\hline & Natural & 47 & 48.0 & 0 & 0.0 & 47 & 38.8 & & \\
\hline & Important & 27 & 27.6 & 23 & 100 & 50 & 41.3 & & \\
\hline & Total & 98 & 100 & 23 & 100 & 121 & 100 & & \\
\hline \multirow{4}{*}{17} & Insignificant & 47 & 50.5 & 0 & 0.0 & 47 & 38.8 & \multirow{4}{*}{59.40} & \multirow{4}{*}{0.000} \\
\hline & Natural & 28 & 30.1 & 0 & 0.0 & 28 & 23.1 & & \\
\hline & Important & 18 & 19.4 & 28 & 100 & 46 & 38.0 & & \\
\hline & Total & 93 & 100 & 28 & 100 & 121 & 100 & & \\
\hline \multirow{3}{*}{18} & Natural & 10 & 16.4 & 0 & 0.0 & 10 & 8.3 & \multirow{3}{*}{56.61} & \multirow{3}{*}{0.000} \\
\hline & Important & 51 & 83.6 & 60 & 100 & 111 & 91.7 & & \\
\hline & Total & 61 & 100 & 60 & 100 & 121 & 100 & & \\
\hline \multirow{4}{*}{19} & Insignificant & 27 & 26.2 & 0 & 0.0 & 27 & 22.3 & \multirow{4}{*}{33.29} & \multirow{4}{*}{0.000} \\
\hline & Natural & 47 & 45.6 & 0 & 0.0 & 47 & 38.8 & & \\
\hline & Important & 29 & 28.2 & 18 & 100 & 47 & 38.8 & & \\
\hline & Total & 103 & 100 & 18 & 100 & 121 & 100 & & \\
\hline \multirow{4}{*}{20} & Insignificant & 10 & 16.9 & 0 & 0.0 & 10 & 8.5 & \multirow{4}{*}{31.62} & \multirow{4}{*}{0.000} \\
\hline & Natural & 19 & 32.2 & 2 & 3.4 & 21 & 17.9 & & \\
\hline & Important & 30 & 50.8 & 56 & 96.6 & 86 & 73.5 & & \\
\hline & Total & 59 & 100 & 58 & 100 & 117 & 100 & & \\
\hline
\end{tabular}

The features which were one of the reasons of abandoning the previous CAIS, are those features which are regarded by the respondents as "important" by $100 \%$ and chi square test is significant: (review table " 3 " for codes).

Table 8 .

\begin{tabular}{ll}
\hline Feature \# & Feature \\
\hline 1 & Ability to prepare full set of financial statements \\
2 & Capabilities to handle a multi-business \\
4 & Ability to customize reports \\
5 & Real-time reporting \\
7 & Strong internal controls \\
12 & Ability to prepare reports on the level of a responsibility center \\
13 & Real-time processing for transactions \\
14 & Developing budgets and analyzing actual and budgeted figures \\
15 & Bank reconciliation and bank transaction management \\
16 & Multi-Currency support \\
17 & Bilingual - Arabic /English support \\
18 & Disaster Recovery feature - Automatic Backup system \\
19 & Internet integration and e-commerce capability \\
\hline
\end{tabular}

The other features which were one of the reasons of abandoning the previous CAIS, are those features which are regarded by the respondents as "important" by approximately $100 \%$ (ranges from $92.3 \%-98.6 \%$ ) and the chi square test is significant are as follow:

Table 9.

\begin{tabular}{lll}
\hline Feature \# & Feature & $\%$ \\
\hline 3 & Frequency of reporting & $95.7 \%$ \\
6 & What if" analysis & $95.7 \%$. \\
8 & Online help & $92.3 \%$ \\
9 & Existence of automatic entries for recurring transactions & $97.6 \%$. \\
10 & Integration with other modules of ERP system & $98.6 \%$. \\
11 & Existence of statistical (non-financial) reports & $94.7 \%$ \\
20 & Excel-Based financial reporting and custom reports & $96.6 \%$. \\
\hline
\end{tabular}


From the previous analysis and since most of the respondents ( $90 \%$ and more) have indicated that the features which they have regarded as "important", are the cause of change, then H5 could be accepted indicating that the features which were one of the reasons of abandoning the previous CAIS, are those features which are regarded by the respondents as "important".

4.5 Testing The Sixth Hypothesis: H6- The Features That the Accountants Require in a CAIS Differ Significantly than Those Features Required by the Decision Maker

By comparing the responses of the managers and the accountants to "question 6" of the questionnaire, and by applying Chi square Test, the following results could be concluded. (review table "3" for codes).

Table 10.

\begin{tabular}{|c|c|c|c|c|c|c|c|c|c|}
\hline \multirow[t]{2}{*}{ Item \# } & \multirow{2}{*}{$\begin{array}{l}\text { Cause } \\
\text { Importance }\end{array}$} & \multicolumn{2}{|c|}{ Decision Maker } & \multicolumn{2}{|c|}{ Accountant } & \multicolumn{2}{|c|}{ Total } & \multirow[t]{2}{*}{ Chi Square } & \multirow[t]{2}{*}{ Sig. } \\
\hline & & \# & $\%$ & $\#$ & $\%$ & \# & $\%$ & & \\
\hline \multirow{3}{*}{1} & Natural & 2 & 3.4 & 4 & 6.5 & 6 & 5.0 & \multirow{3}{*}{0.60} & \multirow{3}{*}{0.438} \\
\hline & Important & 57 & 96.6 & 58 & 94 & 115 & 95.0 & & \\
\hline & Total & 59 & 100 & 62 & 100 & 121 & 100 & & \\
\hline \multirow{4}{*}{2} & Insignificant & 9 & 15.3 & 3 & 4.8 & 12 & 9.9 & \multirow{4}{*}{3.67} & \multirow{4}{*}{0.159} \\
\hline & Natural & 5 & 8.5 & 6 & 9.7 & 11 & 9.1 & & \\
\hline & Important & 45 & 76.3 & 53 & 85 & 98 & 81.0 & & \\
\hline & Total & 59 & 100 & 62 & 100 & 121 & 100 & & \\
\hline \multirow{4}{*}{3} & Insignificant & 4 & 6.8 & 1 & 1.6 & 5 & 4.1 & \multirow{4}{*}{5.93} & \multirow{4}{*}{0.052} \\
\hline & Natural & 23 & 39.0 & 15 & 24.2 & 38 & 31.4 & & \\
\hline & Important & 32 & 54.2 & 46 & 74.2 & 78 & 64.5 & & \\
\hline & Total & 59 & 100 & 62 & 100 & 121 & 100 & & \\
\hline \multirow{4}{*}{4} & Insignificant & 1 & 1.7 & 0 & 0.0 & 1 & 0.8 & \multirow{4}{*}{2.96} & \multirow{4}{*}{0.227} \\
\hline & Natural & 6 & 10.2 & 12 & 19.4 & 18 & 14.9 & & \\
\hline & Important & 52 & 88.1 & 50 & 81 & 102 & 84.3 & & \\
\hline & Total & 59 & 100 & 62 & 100 & 121 & 100 & & \\
\hline \multirow{4}{*}{5} & Insignificant & 5 & 8.5 & 2 & 3.2 & 7 & 5.8 & \multirow{4}{*}{5.61} & \multirow{4}{*}{0.061} \\
\hline & Natural & 20 & 33.9 & 12 & 19.4 & 32 & 26.4 & & \\
\hline & Important & 34 & 57.6 & 48 & 77 & 82 & 67.8 & & \\
\hline & Total & 59 & 100 & 62 & 100 & 121 & 100 & & \\
\hline \multirow{4}{*}{6} & Insignificant & 13 & 22.0 & 5 & 8.1 & 18 & 14.9 & \multirow{4}{*}{5.04} & \\
\hline & Natural & 23 & 39.0 & 25 & 40.3 & 48 & 39.7 & & 0.080 \\
\hline & Important & 23 & 39.0 & 32 & 51.6 & 55 & 45.5 & & \\
\hline & Total & 59 & 100 & 62 & 100 & 121 & 100 & & \\
\hline & Insignificant & 2 & 3.4 & 3 & 4.8 & 5 & 4.1 & & \\
\hline 7 & Natural & 11 & 18.6 & 13 & 21.0 & 24 & 19.8 & 0.29 & 0.864 \\
\hline & Important & 46 & 78.0 & 46 & 74 & 92 & 76.0 & & \\
\hline & Total & 59 & 100 & 62 & 100 & 121 & 100 & & \\
\hline & Insignificant & 19 & 32.2 & 18 & 29.0 & 37 & 30.6 & & \\
\hline 8 & Natural & 21 & 35.6 & 24 & 38.7 & 45 & 37.2 & 0.18 & 0.915 \\
\hline & Important & 19 & 32.2 & 20 & 32.3 & 39 & 32.2 & & \\
\hline & Total & 59 & 100 & 62 & 100 & 121 & 100 & & \\
\hline & Insignificant & 9 & 15.3 & 11 & 17.7 & 20 & 16.5 & & \\
\hline 9 & Natural & 20 & 33.9 & 20 & 32.3 & 40 & 33.1 & 0.14 & 0.931 \\
\hline & Important & 30 & 50.8 & 31 & 50.0 & 61 & 50.4 & & \\
\hline & Total & 59 & 100 & 62 & 100 & 121 & 100 & & \\
\hline & Insignificant & 5 & 8.5 & 3 & 4.8 & 8 & 6.6 & & \\
\hline 10 & Natural & 11 & 18.6 & 10 & 16.1 & 21 & 17.4 & 0.87 & 0.649 \\
\hline & Important & 43 & 72.9 & 49 & 79.0 & 92 & 76.0 & & \\
\hline & Total & 59 & 100 & 62 & 100 & 121 & 100 & & \\
\hline
\end{tabular}




\begin{tabular}{|c|c|c|c|c|c|c|c|c|c|}
\hline \multirow[t]{2}{*}{ Item \# } & \multirow{2}{*}{$\begin{array}{l}\text { Cause } \\
\text { Importance }\end{array}$} & \multicolumn{2}{|c|}{ Decision Maker } & \multicolumn{2}{|c|}{ Accountant } & \multicolumn{2}{|c|}{ Total } & \multirow[t]{2}{*}{ Chi Square } & \multirow[t]{2}{*}{ Sig. } \\
\hline & & $\#$ & $\%$ & $\#$ & $\%$ & \# & $\%$ & & \\
\hline \multirow{4}{*}{11} & Insignificant & 4 & 6.8 & 3 & 4.8 & 7 & 5.8 & \multirow{4}{*}{2.32} & \multirow{4}{*}{0.314} \\
\hline & Natural & 31 & 52.5 & 41 & 66.1 & 72 & 59.5 & & \\
\hline & Important & 24 & 40.7 & 18 & 29.0 & 42 & 34.7 & & \\
\hline & Total & 59 & 100 & 62 & 100 & 121 & 100 & & \\
\hline \multirow{4}{*}{12} & Insignificant & 8 & 13.6 & 6 & 9.7 & 14 & 11.6 & \multirow{4}{*}{1.81} & \multirow{4}{*}{0.405} \\
\hline & Natural & 16 & 27.1 & 12 & 19.4 & 28 & 23.1 & & \\
\hline & Important & 35 & 59.3 & 44 & 71 & 79 & 65.3 & & \\
\hline & Total & 59 & 100 & 62 & 100 & 121 & 100 & & \\
\hline \multirow{3}{*}{13} & Natural & 26 & 44.1 & 19 & 30.6 & 45 & 37.2 & \multirow{3}{*}{2.33} & \multirow{3}{*}{0.127} \\
\hline & Important & 33 & 55.9 & 43 & 69 & 76 & 62.8 & & \\
\hline & Total & 59 & 100 & 62 & 100 & 121 & 100 & & \\
\hline \multirow{4}{*}{14} & Insignificant & 5 & 8.5 & 1 & 1.6 & 6 & 5.0 & \multirow{4}{*}{8.51} & \multirow{4}{*}{0.014} \\
\hline & Natural & 18 & 30.5 & 9 & 14.5 & 27 & 22.3 & & \\
\hline & Important & 36 & 61.0 & 52 & 84 & 88 & 72.7 & & \\
\hline & Total & 59 & 100 & 62 & 100 & 121 & 100 & & \\
\hline \multirow{4}{*}{15} & Insignificant & 5 & 8.5 & 1 & 1.6 & 6 & 5.0 & \multirow{4}{*}{5.18} & \multirow{4}{*}{0.075} \\
\hline & Natural & 24 & 40.7 & 19 & 30.6 & 43 & 35.5 & & \\
\hline & Important & 30 & 50.8 & 42 & 68 & 72 & 59.5 & & \\
\hline & Total & 59 & 100 & 62 & 100 & 121 & 100 & & \\
\hline \multirow{4}{*}{16} & Insignificant & 12 & 20.3 & 12 & 19.4 & 24 & 19.8 & \multirow{4}{*}{0.84} & \\
\hline & Natural & 25 & 42.4 & 22 & 35.5 & 47 & 38.8 & & 0.658 \\
\hline & Important & 22 & 37.3 & 28 & 45 & 50 & 41.3 & & \\
\hline & Total & 59 & 100 & 62 & 100 & 121 & 100 & & \\
\hline & Insignificant & 27 & 45.8 & 20 & 32.3 & 47 & 38.8 & & \\
\hline 17 & Natural & 8 & 13.6 & 20 & 32.3 & 28 & 23.1 & 6.20 & 0.045 \\
\hline & Important & 24 & 40.7 & 22 & 35 & 46 & 38.0 & & \\
\hline & Total & 59 & 100 & 62 & 100 & 121 & 100 & & \\
\hline 18 & Natural & 6 & 10.2 & 4 & 6.5 & 10 & 8.3 & 055 & 0450 \\
\hline 18 & Important & 53 & 89.8 & 58 & 94 & 111 & 91.7 & 0.55 & 0.458 \\
\hline & Total & 59 & 100 & 62 & 100 & 121 & 100 & & \\
\hline & Insignificant & 13 & 22.0 & 14 & 22.6 & 27 & 22.3 & & \\
\hline 19 & Natural & 25 & 42.4 & 22 & 35.5 & 47 & 38.8 & 0.69 & 0.709 \\
\hline & Important & 21 & 35.6 & 26 & 42 & 47 & 38.8 & & \\
\hline & Total & 59 & 100 & 62 & 100 & 121 & 100 & & \\
\hline & Insignificant & 5 & 8.8 & 5 & 8.3 & 10 & 8.5 & & \\
\hline 20 & Natural & 10 & 17.5 & 11 & 18.3 & 21 & 17.9 & 0.72 & 0.991 \\
\hline & Important & 42 & 73.7 & 44 & 73.3 & 86 & 73.5 & & \\
\hline & Total & 57 & 100 & 60 & 100 & 117 & 100 & & \\
\hline
\end{tabular}

Based on the previous chi square test, it could be concluded that there are only two features which differ significantly between accountants and managers.

- Feature no. 14 which is "Developing budgets and analyzing actual and budgeted figures". It is clear that the accountants required this features more than the decision makers, This could be explained that the accountants greatly need such a feature during budget preparation, while the decision makers uses the budget and they don't prepare its details and that is why they don't regard the preparation feature as important as the accountants.

- Feature no. 17 which is "Bilingual Arabic/English support". It is clear that the decision makers require this feature more than accountants. However, this feature is of low importance since there are only $38 \%$ of responses in the whole sample.

On the other hand, the other features mentioned in the questionnaire do not differ significantly from a decision maker to an accountant perspective. 
Accordingly there are only one feature in CAIS that differ significantly between accountants and decision makers and the other nineteen features did not differ significantly. Hence, we can reject the $6^{\text {th }}$ hypothesis of the research and accept the alternative hypothesis indicating that the features that the accountants require in a CAIS does not differ significantly than those features required by the managers.

\section{Conclusions and Recommendations}

\subsection{Conclusions}

This paper investigates the experience of companies that have changed their CAIS more than once. The aim of such investigation is to rationalize the investment decision in such a field. The results revealed that there is a significant change in the relative importance of the criteria used to choose CAIS from the first to the second time of implementation. It is concluded that the mostly required features by the accountants are present in the currently implemented CAIS and that the features that were the reason of abandoning the previous CAIS are present in the currently adopted one. As expected that the features which were one of the reasons of abandoning the previous accounting system, are those features which are regarded by the accountant as "important". Finally, the opinion of the managers and the accountants differed significantly only in one feature while there is no significant change regarding the other features.

\subsection{Recommendations}

Based on the above conclusions and findings the researcher recommends the following recommendations to the companies which are planning to introduce or update their CAIS system in order to rationalize their investments in such a field:

- Companies should consider the change in priorities mentioned in this research while choosing their new CAIS to learn from the experience of others.

- Companies should concentrate on the main features required by both managers and accountants when choosing a CAIS. Other features which would appear valuable, and would increase the cost of the CAIS, but are neither required by the accountants nor by the managers. Hence, it should be eliminated as it would be regarded as extra cost without having a real added value.

- There are some companies which provide various types of CAIS which fulfills the needs of various types of businesses and companies. However, such CAIS varies in prices and in performance and the support provided by its developers, in addition to some differences in functions and specifications. Such variances and differences in the wide range spectrum which the companies provide make it fairly difficult for small and midsize companies to choose the appropriate CAIS.(Maheshwari \& McLain, 2006). Based on that, the researcher recommends designing a model to allow companies to align their needs with the features present in the different CAIS available. Such a model should include the different variables such as the needs, the resources available to the companies and the different features of the CAIS, then uses such variables to suggest certain CAIS solutions to companies. This would be a topic of another research.

\section{References}

Alkary, A. (2005). Cost of investment in information systems and its relation with organizational perofrmance an applied studied on the commercial banks in jordan. [- تكلفة الاستثمار فى أنظمة المعلومات وعلافتها بأداء المنظمات (24) مجلة علوم أنسانية [در اسة تطبيقية على البنوك التجارية فى الأردن

Asta Raupeliene, \& Linas Stabingis. (2003). Development of a model for evaluating the effectiveness of accounting information systems. EFITA 2003 Conference, Debrecen, Hungary. (July) 339-445.

Ismail, N. A., \& King, M. (2005). Firm performance and AIS alignment in malaysian SMEs. International Journal of Accounting Information Systems, 6(4), 241-259. http://dx.doi.org/10.1016/j.accinf.2005.09.001

Ivancevich, S. H., Ivancevich, D. M., \& Elikai, F. (2010). Accounting software selection and satisfaction. The CPA Journal, 80(1), 66-72.

Maheshwari, S. K., \& McLain, M. P. (2006). Selection of accounting software tools for small business: Analytical hierarchy process approach. Proceedings of the Academy of Accounting and Financial Studies, Reno. , 11(2), 39-45.

Meall, L. (2009). How to choose large enterprise software. The Accountancy Age Guide Series, (21st May), 19.

Nicolaou I., A. (2000). A contingency model of perceived effectiveness in accounting information systems: Organizational coordination and control effects. International Journal of Accounting Information Systems, 1, 91-105. http://dx.doi.org/10.1016/S1467-0895(00)00006-3 
Nord, G. D., Jeretta Horn Nord, \& Xu, H. (2005). An investigation of the impact of organization size on data quality issues. Journal of Database Management, 16(3), 58-71. http://dx.doi.org/10.4018/jdm.2005070104

Redman, T. C. (1992). Data quality: Management and technology. New York: Bantam Books.

Tate, J. (1999). How to select new business software. Financial Management, 77(4), 52-54.

$\mathrm{Xu}, \mathrm{H}$. (2009). Data quality issues for accounting information systems' implementation: Systems, stakeholders, and organizational factors. Journal of Technology Research, 1, 1-11.

Yau, C., \& Auyeung, P. K. (June 29 - July 2, 1995). Issues of accounting information system for the year 2000. The Second Pacific Asia Conference on Information Systems, PACIS, Singapore. 440-447.

Appendix I. General Information

Please check in front the appropriate answer that fits your company.

1. Company field of business

\begin{tabular}{l|l|l|l|l|l} 
Industrial & Trading & Services & Distribution & Banking & Others : (Please Specify) \\
$\square$ & $\square$ & $\square$ & $\square$ & $\square$ & $\square$
\end{tabular}

2- Number of Employees

\begin{tabular}{l|l|l|}
$1-49$ & $50-100$ & Over 100 \\
$\square$ & $\square$ & $\square$
\end{tabular}

\section{Company's Capital}

\begin{tabular}{l|l|l|l}
$\begin{array}{l}\text { Less than one } \\
\text { Million }\end{array}$ & 1 Million to 10 & 10 Million to 50 & Over 50 Million \\
$\square$ & Million & Million & \\
$\square$ & $\square$ & $\square$
\end{tabular}

4. What are the priorities which you considered when selecting the Computerized Accounting Information System (CAIS hereafter) which you implemented lately? Please put a number from 1 to 10 in front of each factor. Please do not repeat the number twice. Where " 1 " is the most important, and " 10 " is the least important.

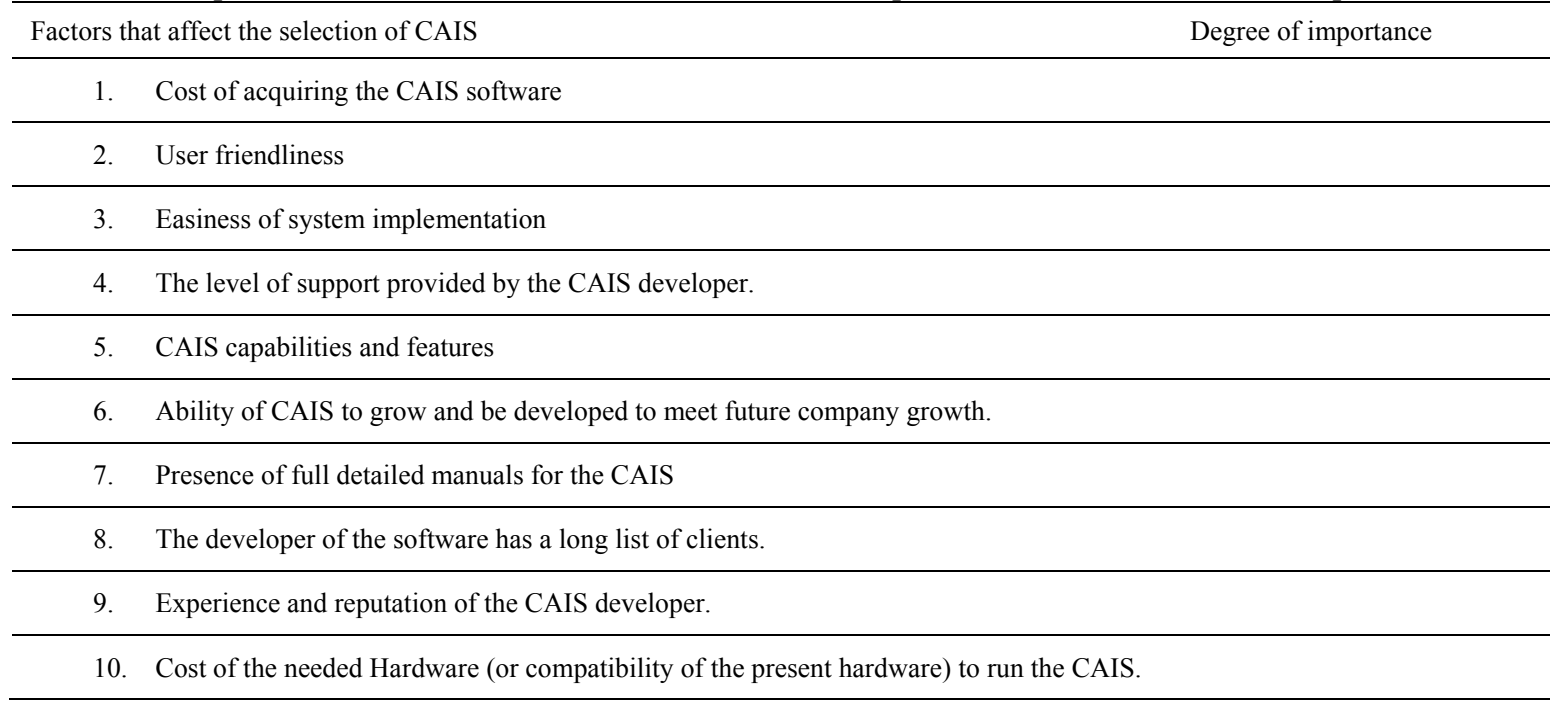


5. If you have implemented a previous CAIS before, what were your priorities when you selected such a system?

Factors that affect the selection of CAIS

1- Cost of acquiring the CAIS software .

2- $\quad$ User friendliness

3- Easiness of system implementation

4- The level of support provided by the CAIS developer.

5- CAIS capabilities and features

6- Ability of CAIS to grow and be developed to meet future company growth.

7- Presence of full detailed manuals for the CAIS

8- The developer of the software has a long list of clients.

9- Experience and reputation of the CAIS developer.

10- Cost of the needed Hardware (or compatibility of the present hardware) to run the CAIS.

6. Please indicate the importance of each of the following features which you would be considering when selecting a CAIS. Please check only one box in front of each feature:

Mostly required features in CAIS from an accountant/decision maker perspective: (What you hope to have in the system.)

\begin{tabular}{|c|c|c|c|}
\hline Feature & & Important Neutral & Insignificant \\
\hline $1-$ & Ability to prepare full set of financial statements. & & \\
\hline 2. & Capabilities to handle multi-business & & \\
\hline 3. & Frequency of reporting. & & \\
\hline 4. & Ability to customize reports. & & \\
\hline 5. & Real-time reporting. & & \\
\hline 6. & "What if" analysis. & & \\
\hline 7. & Strong internal controls. & & \\
\hline 8. & Online help. & & \\
\hline 9. & Existence of automatic entries for recurring transactions. & & \\
\hline & Integration with other modules of ERP system. & & \\
\hline 11. & Existence of statistical (non-financial) reports. & & \\
\hline 12. & Ability to prepare reports on the level of a responsibility centre. & & \\
\hline & Real-time processing for transactions. & & \\
\hline 14. & Developing budgets and analyzing actual and budgeted figures & & \\
\hline & Bank reconciliation and bank transaction management. & & \\
\hline 16. & Multi-Currency support & & \\
\hline 17. & Bilingual - Arabic /English support & & \\
\hline 18. & Disaster Recovery feature - Automatic Backup system & & \\
\hline 19. & Internet integration and e-commerce capability. & & \\
\hline 20. & Excel-Based financial reporting and custom reports. & & \\
\hline
\end{tabular}

7. The present features of CAIS already present in your implemented system.

Please indicate which of the following features are already available in your system. Only put one check in front of each feature. If you have implemented a new CAIS system instead of an older one, please check in the last column to the right which of these features was one of the reasons of such a change. In case that this is your first CAIS, then leave the last column to the right empty. 


\begin{tabular}{|c|c|c|c|}
\hline Feature & $\begin{array}{l}\text { Available in the } \\
\text { current system }\end{array}$ & $\begin{array}{l}\text { Not available in the } \\
\text { current system }\end{array}$ & $\begin{array}{l}\text { This is one of the reasons that lead to the } \\
\text { change from the older CAIS to the current } \\
\text { one. }\end{array}$ \\
\hline \multicolumn{4}{|l|}{$\begin{array}{l}\text { 1. Ability to prepare full set of } \\
\text { financial statements. }\end{array}$} \\
\hline \multicolumn{4}{|l|}{$\begin{array}{l}2 . \quad \text { Capabilities to handle } \\
\text { multi-business }\end{array}$} \\
\hline Frequency of reporting. & & & \\
\hline Ability to customize reports. & & & \\
\hline Real-time reporting. & & & \\
\hline "What if" analysis. & & & \\
\hline Strong internal controls. & & & \\
\hline Online help. & & & \\
\hline \multicolumn{4}{|l|}{$\begin{array}{l}\text { 9. Existence of automatic entries for } \\
\text { recurring transactions. }\end{array}$} \\
\hline \multicolumn{4}{|l|}{$\begin{array}{l}10 . \quad \text { Integration with other modules of } \\
\text { ERP system. }\end{array}$} \\
\hline \multicolumn{4}{|l|}{$\begin{array}{l}11 . \quad \text { Existence of statistical } \\
\text { (non-financial) reports. }\end{array}$} \\
\hline \multicolumn{4}{|l|}{$\begin{array}{l}\text { 12. Ability to prepare reports on the } \\
\text { level of a responsibility center. }\end{array}$} \\
\hline \multicolumn{4}{|l|}{$\begin{array}{l}13 . \quad \text { Real-time processing for } \\
\text { transactions. }\end{array}$} \\
\hline \multicolumn{4}{|l|}{$\begin{array}{l}14 . \quad \text { Developing budgets and analyzing } \\
\text { actual and budgeted figures }\end{array}$} \\
\hline \multicolumn{4}{|l|}{$\begin{array}{l}15 . \quad \text { Bank reconciliation and bank } \\
\text { transaction management. }\end{array}$} \\
\hline Multi-Currency support & & & \\
\hline \multicolumn{4}{|l|}{ Bilingual - Arabic /English } \\
\hline \multicolumn{4}{|l|}{$\begin{array}{l}18 . \quad \text { Disaster Recovery feature - } \\
\text { Automatic Backup system }\end{array}$} \\
\hline \multicolumn{4}{|l|}{$\begin{array}{l}19 . \quad \text { Internet integration and } \\
\text { e-commerce capability. }\end{array}$} \\
\hline $\begin{array}{l}20 . \quad \text { Excel-Based financial reporting } \\
\text { and custom reports. }\end{array}$ & & & \\
\hline
\end{tabular}

